\title{
EDITORIAL
}

\section{New year, new issue}

(c) The Author(s), under exclusive licence to European Society of Human Genetics 2021

European Journal of Human Genetics (2022) 30:1-2; https://doi.org/ 10.1038/s41431-021-01014-5

In this issue we publish a collection of papers devoted to the genetics of hearing loss [1-4]. Prof Roux has produced an insightful commentary on these to provide a summary [5]. We continue to seek suggestions for topic collections and special issues. By gathering together related reviews and research papers we hope to facilitate a broader understanding of the issues.

What then can be found in this month's issue of European Journal of Human Genetics for the practicing Clinical Geneticist? Bruel and colleagues characterise variants in ITSN1 as a novel genetic cause for neurodevelopmental disorders [6]. The ITSN1 protein is highly expressed in neurons and plays a role in neurodevelopment. The associated phenotypes include intellectual disability and autism. Both loss-of-function and missense variants were identified. Variants in SOX11 have been associated with a Coffin-Siris phenotype. Hanker et al describe a new family, demonstrating transmission from a mildly affected mother [7]. Oculo-motor apraxia is confirmed as a feature. White-Sutton syndrome is associated with variants in POGZ. This new series defines the dysmorphism and identifies retinitis pigmentosa and cleft palate as associations [8]. The prenatal phenotype of bi-allelic PKNP variants is described by Neuser [9]. Post-mortem findings included brain hypoplasia and evidence of a neuronal migration disorder.

While clinicians may recognise the benefits of genetic testing for patients; patients and families may not always agree. Ahmed and colleagues present a decision support aid to facilitate cascade screening for beta-thalasaemia [10]. The sharing of genetic information within families can also be problematic. Finn and colleagues identify a number of perceived barriers to sharing cancer genetic risk information with relatives [11]. Emphasising the benefits of sharing the cancer risk information may encourage discussion. Many people seek genetic testing to understand their disease risk via non clinical routes. For example, polygenic risk scores from private providers. A study in this month's EJHG suggests that over half of people who obtain a polygenic risk score have an adverse psychological reaction and few are equipped to fully understand the implications [12]. Nonetheless, there is some limited evidence that polygenic risk scores can lead to improvements in health behaviour [13].

This month we also have papers of interest to laboratory geneticists. A study of variants in the NPC1 gene will help clarify variant interpretation for diagnosis of Niemann-Pick disease [14]. They demonstrate that a polymorphic variant in NPC1 is required to be present before a synonymous variant can activate cryptic splicing and lead to a frameshift. Evidence continues to emerge that exome sequencing can be a cost effective diagnostic strategy. First tier exome sequencing could save over euros 3000 per patient [15]. Laboratory managers can be increasingly confident that exome sequencing could be offered as the initial test of choice in neurodevelopmental disorders.
Alisdair McNeill ${ }^{1,2 \otimes}$

'Department of Neuroscience, The University of Sheffield, Sheffield, UK. ${ }^{2}$ Sheffield Clinical Genetics Department, Sheffield Children's Hospital NHS Foundation Trust, Sheffield, UK.

凶email: a.mcneill@sheffield.ac.uk

\section{REFERENCES}

1. Bharadwaj T, Schrauwen I, Rehman S, Liaqat K, Acharya A, Giese APJ, et al. ADAMTS1, MPDZ, MVD, and SEZ6: candidate genes for autosomal recessive nonsyndromic hearing impairment. Eur J Hum Genet. 2021. https://doi.org/ 10.1038/s41431-021-00913-x

2. Bueno AS, Nunes K, Dias AMM, Alves LU, Mendes BCA, Sampaio-Silva J, et al. Frequency and origin of the c.2090T>G p.(Leu697Trp) MYO3A variant associated with autosomal dominant hearing loss. Eur J Hum Genet. 2021. https://doi.org/ 10.1038/s41431-021-00891-0

3. O'Brien A, Aw WY, Tee HY, Naegeli KM, Bademci G, Tekin M, et al. Confirmation of COL4A6 variants in X-linked nonsyndromic hearing loss and its clinical implications. Eur J Hum Genet. 2021. https://doi.org/10.1038/s41431-02100881-2

4. Vaché $C$, Baux $D$, Bianchi J, Baudoin $C$, Faugère $V$, Francannet $C$, et al. Reclassification of a TMC1 synonymous substitution as a variant disrupting splicing regulatory elements associated with recessive hearing loss. Eur J Hum Genet. 2021. https://doi.org/10.1038/s41431-021-01010-9

5. Roux A-F. Deafness-family matters. Eur J Hum Genet. 2021. https://doi.org/ 10.1038/s41431-021-01006-5

6. Bruel AL, Vitobello A, Thiffault I, Manwaring L, Willing M, Agrawal PB, et al. ITSN1: a novel candidate gene involved in autosomal dominant neurodevelopmental disorder spectrum. Eur J Hum Genet. 2021. https://doi.org/10.1038/s41431-02100985-9

7. Hanker B, Gillessen-Kaesbach G, Hüning I, Lüdecke HJ, Wieczorek D. Maternal transmission of a mild Coffin-Siris syndrome phenotype caused by a SOX11 missense variant. Eur J Hum Genet. 2021. https://doi.org/10.1038/s41431-02100865-2

8. Murch O, Jain V, Benneche A, Metcalfe K, Hobson E, Prescott K, et al. Further delineation of the clinical spectrum of White-Sutton syndrome: 12 new individuals and a review of the literature. Eur J Hum Genet. 2021. https://doi.org/ 10.1038/s41431-021-00961-3

9. Neuser S, Krey I, Schwan A, Abou Jamra R, Bartolomaeus T, Döring J, et al. Prenatal phenotype of PNKP-related primary microcephaly associated with variants affecting both the FHA and phosphatase domain. Eur J Hum Genet. 2021. https:// doi.org/10.1038/s41431-021-00982-y

10. Ahmed S, Jafri H, Rashid $Y$, Ehsan $Y$, Bashir S, Ahmed M. Cascade screening for beta-thalassemia in Pakistan: development, feasibility and acceptability of a decision support intervention for relatives. Eur J Hum Genet. 2021. https://doi. org/10.1038/s41431-021-00918-6

11. Finn KS, Pacyna J, Azevedo Tsou C, Jewel Samadder N, Sharp R. Patient-reported anticipated barriers and benefits to sharing cancer genetic risk information with family members. Eur J Hum Genet. 2021. https://doi.org/10.1038/s41431-02100890-1

12. Peck L, Borle K, Folkersen L, Austin J. Why do people seek out polygenic risk scores for complex disorders, and how do they understand and react to results? Eur J Hum Genet. 2021. https://doi.org/10.1038/s41431-021-00929-3

13. Oliveri S, Cincidda C, Ongaro G, Cutica I, Gorini A, Spinella F, et al. What people really change after genetic testing (GT) performed in private labs: results from an Italian study. Eur J Hum Genet. 2021. https://doi.org/10.1038/s41431-02100879-w 
14. Bychkov I, Filatova A, Perelman G, Proshlyakova T, Korotkova D, Klyushnikov S, et al. Additive effect of frequent polymorphism and rare synonymous variant alters splicing in twin patients with Niemann-Pick disease type C. Eur J Hum Genet. 2021. https://doi.org/10.1038/s41431-021-00898-7

15. Klau J, Abou Jamra R, Radtke M, Oppermann H, Lemke JR, Beblo S, et al. Exome first approach to reduce diagnostic costs and time-retrospective analysis of 111 individuals with rare neurodevelopmental disorders. Eur J Hum Genet. 2021. https://doi.org/10.1038/s41431-021-00981-z

\section{AUTHOR CONTRIBUTIONS}

AM conceived and wrote this article.

\section{COMPETING INTERESTS}

The author declares no competing interests.

\section{ADDITIONAL INFORMATION}

Correspondence and requests for materials should be addressed to Alisdair McNeill.

Reprints and permission information is available at http://www.nature.com/ reprints

Publisher's note Springer Nature remains neutral with regard to jurisdictional claims in published maps and institutional affiliations. 